For citation please use CYELP, volume 1. More information available at www.cyelp.com

\title{
INTER-COURT CONSTITUTIONAL DIALOGUE AFTER THE ENLARGEMENT - IMPLICATIONS OF THE CASE OF UNIVERSITY PROFESSOR KÖBLER
}

\author{
Jan Komárek ${ }^{*}$
}

Summary: This paper discusses the Köbler case, in which the Court of Justice confirmed that the principle of Member States' liability for breaches of Community law (the "Francovich" Principle) also applies to breaches committed by national judiciaries. The author looks at this decision and, more importantly, at the Court's reasoning from the point of view of the concept of multi-constitutionalism, which, he believes, is a viable model for a pluralistic entity such as the European Union. Several shortcomings of the decision are discussed in this paper, including the Court's avoidance of difficult questions by reference to the principle of national procedural autonomy, or its unpersuasive comparative reasoning. One further shortcoming is the lack of any balancing argumentation, which would have seemed appropriate in a case where two legal principles (the effectiveness of Community law, on the one hand, and legal certainty and res judicata, on the other) stood in opposition. In the final part of the paper, the author points out that the problem of gaining acceptance for this decision may be even more difficult with regard to judges in the new Member States, as their legal systems are simultaneously undergoing not only Europeanisation but also transition.

\section{InTRODUCTION}

On the doorstep of Enlargement, the European Union is "in search of a public philosophy". ${ }^{1}$ Classical efforts to explain the complex constitutional coexistence between the Member States and the developing EU legal order have so far failed. ${ }^{2}$ The Enlargement highlights the need to find a new constitutional theory and practice for an even more diverse Union. New Member States will bring new issues, or at least new concerns, resulting from their different historical experiences (e.g. constitutional sensitivity due to their recently earned sovereignty and different views on the protection of fundamental rights). ${ }^{3}$

- LL.M. Stockholm, 2004, Diploma of the AEL-EU Law Session, EUI Florence, 2004. Ministry of Foreign Affairs of the Czech Republic, Department of EC Law (Agency for the Czech Republic before the Court of Justice of the EC). Further comments are welcomed at jankomarek@centrum.cz. I would like to thank my colleagues Katinka Persson, Martin Mörk and James Brand for their corrections of the text and comments thereon. This paper was prepared for presentation at the international seminar within the framework of the Jean Monnet Module "Advanced Issues of European Law" held in IUC Dubrovnik, February 29 - March 7, 2004

${ }^{1}$ For an outline see, inter alia, I. Ward, A Critical Introduction to European Law, London, Lexis Nexis Butterworths, 2003, p. 246-280 (Ch. 8 bearing this title) or in more details A. Verhoeven, The European Union IN SEARCH OF a Democratic and Constitutional Theory, Kluwer Law International, The Hague/London/New York, 2002.

${ }^{2}$ See, generally, for example, J.H.H.Weiler, Constitution of Europe, Cambridge, Cambridge University Press, 1999, p. 221-237 (Introduction: The Reformation of European Constitutionalism), at p. 230-234.

${ }^{3}$ See, for example, W. Sadurski, Constitutionalization of the EU and the Sovereignty Concerns of the New Accession States: The Role of the Charter of Rights, EUI Working Paper Law 11/03, www.iue.it/PUB/Law03-10.pdf (30.9.2003). From this point of view, the Schmidberger Case - C-112/00, [2003] ECR I-5659 is extremely important. Cf. case note by C. Brown, [2003] 40 CMLRev, 1499. For recent examples, see A. Sajo, Learning Cooperative Constitutionalism the Hard Way: the Hungarian Constitutional Court Shying Away from EU Supremacy, Zeitschrift für Staats- und Europawissenschaften (ZSE) 3/2004, p.351-371 and the decision of the Polish Constitutional Tribunal of April 272005 - P 1/05, invalidating national law implementing the European Arrest Warrant

$$
\text { see }
$$
the press

release available at 
Multi-constitutionalism seeks to be a response to this search for a public philosophy. ${ }^{4}$ It rejects the idea of hierarchy in the multiplicity of legal orders, which compose the legal order of the EU. This is also reflected in a positive way by Art. 6(3) EU or even more clearly by Art. I-5(1) of the Treaty establishing a Constitution for Europe, ${ }^{5}$ which calls for respect of the Member States' national constitutional identities. Debates concerning the meaning of Art. $10 \mathrm{EC}$ also confirm the need for real co-operation, as opposed to subordination of the national legal orders and their judiciaries to the "supreme legal order of the EU".

Both the Court of Justice and national courts play an important role in the Integration Project, ${ }^{6}$ and part of this "constitutional paradigm reform" must therefore also embrace views on the intercourt dialogue. ${ }^{7}$ This "dialogue" means something more than merely the duty of national judges to adjust their respective legal orders to the tasks of integration. The word "dialogue" implies an exchange between parties that somehow respect each other. Therefore, in order for a real intercourt dialogue to take place and be effective, one must also expect changes to be made at the EU level. ${ }^{\text {7a }}$

The recent case of $\mathrm{Mr} \mathrm{Köbler}{ }^{8}$ is in this context interesting for several reasons. In this case, the Court of Justice had to manoeuvre in a very sensitive area of law: the responsibility of a state for acts committed by its judicial bodies. Promoting the effectiveness of Community law at the time of Enlargement seems to be the main ratio behind the reasoning of the Court. However, even for proponents of Community law in national legal orders, the judgement remains unsatisfactory and deserves critique on the way the Court has reasoned. The purpose of this paper is to present the possible critique and put it into the context of the inter-court constitutional dialogue.

In particular, the second part of the paper will present the facts of the case and the decision of the Court of Justice. Then, in the third part, some weaknesses in the reasoning will be demonstrated: the unresponsiveness to arguments of governments intervening in the case regarding different standards of liability for Community courts and their national counterparts, the unconvincing comparative reasoning of the Court, and a contradiction in the judgement in dealing with balancing arguments and the application of a "sufficiently-serious-breach test". Lastly, the fourth part will show possible (or even necessary) responses from a national level. In particular, the fact that the highest courts at a national level ${ }^{9}$ should respect their duty resulting from Art. 234 EC to refer preliminary questions to the Court of Justice. They should also use the case-law of the Court as at least a persuasive authority or even a source of law when arguing on the national level.

\footnotetext{
http://www.trybunal.gov.pl/eng/summaries/documents/EAW_release_27_04_05_new.pdf (2.5.2005).

${ }^{4}$ See, inter alia, N. Mac Cormick, Questioning Sovereignty, Oxford, OUP, 1999; F.C. Mayer and I. Pernice, De la consitution composée de l'Europe, [2000] 35 RTD eur 623, N. Walker, The Idea of Constitutional Pluralism, EUI Working Paper Law 2002/01, http://www.iue.it/PUB/law02-1.pdf (23.10.2003).

${ }^{5}$ OJ 2004 C 310.

${ }^{6}$ See A.M. Slaughter, A.S. Sweet, J.H.H. Weiler (eds.), The European Court and National Courts - Doctrine and Jurisprudence, Oxford, Hart Publishing, 1998 or see n.2 (Weiler 1999), p. 188-218 ("The Least Dangerous Branch: A Retrospective and Prospective of the European Court of Justice in the Arena of Political Integration").

${ }^{7}$ F.C. Mayer, The European Constitution and the Courts - Adjudicating European constitutional law in a multilevel system. The Jean Monnet Program Working Papers 9/03, http://www.jeanmonnetprogram.org/papers/03/03090103.html (11.1. 2004), pp. 29-41.

${ }^{7 a}$ See a deeper reflection of this topic J. Komárek,, Federal Elements in the Community Judicial System: Building Coherence in the Community Legal Order, [2005] 42 CMLRev. 9.

${ }^{8}$ Case C-241/01 Gerhard Köbler v. Republik Österreich [2003] ECR I-10239.

${ }^{9}$ For an outline of these courts, see n. 7 (Mayer 2003), p. 3-4.
} 


\section{The Köbler Case}

In 1996 Mr Köbler applied for a special length-of-service increment for university professors in Austria. He did so even though he had completed the requested 15 years' period as a professor also in Member States other than Austria. The requirement of the relevant law was to complete the period at Austrian universities only; however, he claimed that such a requirement led to indirect discrimination contrary to the Treaty, in particular to the Free Movement of Workers. ${ }^{10}$ Nevertheless, his application was dismissed by the administrative authorities and his dispute eventually reached the Austrian Supreme Court (Verwaltungsgerichtshof). This court, in the course of the proceedings, then referred the question to the Court of Justice. The question was whether work of equal value performed in another Member State (such as that of Mr Köbler as a university professor outside Austria) must be taken into account in exactly the same way as such work performed in the Member State applying a salary scheme in which remuneration depends, inter alia, on length of service (i.e. in Austria). ${ }^{11}$ Since the same issue had been dealt with by the Court of Justice in Schöning-Kougebetopoulou, ${ }^{12}$ the Registrar of the Court asked the Verwaltungsgerichtshof whether it deemed its reference necessary in the light of this judgement. The Verwaltungsgerichtshof subsequently informed the parties that the legal issue, which was the subject-matter of the question submitted for a preliminary ruling, seemed to be resolved in favour of the applicant, Mr Köbler, and withdrew its referral. However, the story did not have a happy ending. The Verwaltungsgerichtshof changed its view on the contested increment and held that it was in fact a special bonus for loyalty (and not a bonus for length of service). According to the Verwaltungsgerichtshof's interpretation of the Schöning-Kougebetopoulou judgement, the requirement to complete the whole 15-year period as a university professor only in Austria was justified. Without referring any further question to the Court of Justice, it finally dismissed $\mathrm{Mr}$ Köbler's claim for obtaining the increment.

The Köbler Case could very well have ended there, since at that time no Community remedy against a decision of a national court, which disregarded its obligations from the Treaty, seemed to exist. ${ }^{13,14}$ The cases where national courts infringed the Treaty were sometimes found in annual reports of the Commission on monitoring the application of the Community law, but the Commission had never brought a Member State to the Court in an infringement procedure. ${ }^{15}$

The Brasserie de Pêcheur/Factortame III judgement ${ }^{16}$ indicated a possible change in that regard:

\footnotetext{
${ }^{10}$ Article 39 EC and Article 7(1) of Council Reg. 1612/68 [1968] OJ L 257/2 of 15 October 1968 on the freedom of movement for workers within the Community.

${ }^{11}$ Cf. Case C- 382/97 Gerhard Köbler v. Bundesminister für Wissenschaft, Forschung und Kunst [1998] OJ C 7/9.

${ }^{12}$ Case C-15/96 Schöning-Kougebetopoulou [1998] ECR I-47.

${ }^{13}$ The French Conseil d'Etat is perhaps most "famous" in that matter when, for example, it denied the directives' direct effect in the case Cohn-Bendit. Cf. case note by P.J.G. Kapteyn, [1979] 16 CMLRev. 701 or A. Oppenheimer, The Relationship between European Community Law and National Law: the Cases, Cambridge, Cambridge University Press, 1994, p. 316-334 where the text of the decision may be found.

${ }^{14}$ Cf., inter alia, H.G. Schermers and D.F. Waelbroeck, Judicial Protection in the European Union, $6^{\text {th }}$ Ed., The Hague/London/New York, Kluwer Law International, 2001; or K. Lenaerts, D. Arts and R. Bray (eds.), Procedural Law of the European Union, London, Sweet\&Maxwell, 1999, p. 53. Both of them were still indicating the possibility to claim damages from a Member State.

${ }^{15}$ This has also changed: cf. Case C-129/00 Commission v. Italy [2003], 9.12. 2003, not yet reported. See n. 7a (Komárek 2005) and a case comment D. Simon, La condamnation indirecte du 'manquement judiciaire': Le juge national doit être asservi par le legislateur au respect du droit communautaire. Europe, vol. 14, No. 3/2004, p. 8

${ }^{16}$ Joined Cases C-46 and 48/93 Brasserie de Pêcheur/ Factortame III [1996] ECR I-1029.
} 
For citation please use CYELP, volume 1. More information available at www.cyelp.com

[The principle of State liability] holds good for any case in which a Member State breaches Community law, whatever be the organ of the State whose act or omission was responsible for the breach. In addition, in view of the fundamental requirement of the Community legal order that Community law be uniformly applied [...] the obligation to make good damage caused to individuals by breaches of Community law cannot depend on domestic rules as to the division of powers between constitutional authorities. [...I]n international law a State whose liability for breach of an international commitment is in issue will be viewed as a single entity, irrespective of whether the breach which gave rise to the damage is attributable to the legislature, the judiciary or the executive. This must apply a fortiori in the Community legal order $[\ldots]^{17}$

The fact also that courts' decisions may invoke Member States' liability was mentioned by Advocate General Léger in Hedley Lomas $^{18}$ and discussed by scholars. ${ }^{19}$ However, opinions contesting such a possibility still existed. ${ }^{20}$

Mr Köbler was the first to turn the debate into reality and claimed damages against Austria in the Regional Civil Court (Landesgericht für Zivilrechtssachen Wien). He claimed reparation of the loss which he had allegedly suffered as a result of the non-payment to him of a special length-ofservice increment. He maintained that the judgement of the Verwaltungsgerichtshof infringed directly applicable provisions of Community law, as interpreted by the Court of Justice in the judgements in which it held that a special length-of-service increment does not constitute a loyalty bonus.

Hearing the case of liability claim, the Landesgericht then referred to the Court of Justice several questions which may be summarised as follows: the possibility of a Member State to be held responsible for an act of its supreme court (question of principle); the conditions of such liability (question of conditions); and then the case of Mr Köbler itself (question of application). The last of the questions referred to shows the conundrum of judicial responsibility for national judicial systems. Such responsibility leads to a situation where judges are forced to judge other judges. And paradoxically, it is possible that the claim for damages may end in the same court which gave the judgement breaching Community law. No wonder the Landesgericht invited the Court of Justice into the realm of "national procedural autonomy", leaving the ruling on the substantive part of Mr Köbler's claim for this Court.

The decision of the Court of Justice confirmed the opinions affirming the possibility of such liability and stated that a Member State must make good the damage even if caused by a breach of Community law committed by a supreme court. It then more or less applied the conditions of the Brasserie de Pêcheur/Factortame III test. Unfortunately for Mr Köbler, it then found that the breach in question was not "sufficiently serious".

\footnotetext{
${ }^{17}$ Ibid., paras. 32-34.

${ }^{18}$ Opinion of Léger AG in Case C-5/94 R. v. Ministry of Agriculture, Fisheries\&Food, ex parte Hedley Lomas [1996] ECR I-2553, para. 114.

${ }^{19}$ H. Toner, Thinking the Unthinkable? State Liability for Judicial Acts after Factortame (III), [1997] 17 YBEL 165, G. Anagnostaras, The Principle of State Liability for Judicial Breaches: The Impact of European Community Law [2001] 7 EPL 281 are the most detailed analyses published in English.

${ }^{20}$ For example, J. Steiner, Limits of State Liability for Breach of EU Law. [1998] 4 EPL 69, p. 91-92.
} 


\section{Questions POSED BY THE JUDGEMENT}

Though the judgement dealt directly with the question of judicial breaches of Community law, it left many points open. Let us now analyse the reasoning of the Court of Justice, focusing on its obscurities which should be further discussed and possibly clarified by the Court's further caselaw. We will focus on three of them: the different standards for liability of the Member States and the Community by which intervening governments counter-argued against the liability; secondly, the Court's rather unconvincing comparative legal reasoning; and finally, the contradictions in the Court's reasoning in applying the test of a sufficiently serious breach to the case of $\mathrm{Mr}$ Köbler.

\subsection{Conditions of liability - still the same for Member States as for the Community?}

As mentioned above, a dispute for damages may reach by appeals the Supreme Court, which is responsible for the decision in question. Of course, in the Court of Justice's view the resolution of this problem is clear: it is for Member States to designate the competent courts and lay down the detailed procedural rules for legal proceedings intended to fully safeguard the rights which individuals derive from Community law. ${ }^{21}$

However, the same problem may well arise before the Court of Justice itself: what if the Court of Justice breached Community law by its own decision? In Bergaderm the Court confirmed that "the conditions, under which the State may incur liability, cannot, in the absence of particular justification, differ from those governing the liability of the Community in like circumstances". ${ }^{22}$ The Governments of Austria and the United Kingdom argued that holding a Member State responsible for a judicial act does not have its mirror possibility in the case of breaches committed by the Court of Justice, for the simple reason that there is no court in which one may raise such a claim.

Advocate General Léger has resolved the problem too simply: the liability in this case is excluded because the Court of Justice acts as the Supreme Court of the Community and its decisions cannot be reviewed by another court or tribunal! ${ }^{23}$ How can Member States accept this reasoning when the Court wants them to find how to make possible liability claims against their own supreme courts?

The Advocate General's statement that "we cannot infer that the rules governing Member State liability and the rules in respect of the Community must develop in strict parallel"24 is particularly interesting since the Court has established the whole doctrine of Member State liability on this parallel with liability of the Community (the only one mentioned expressly in the

\footnotetext{
${ }^{21}$ Köbler, see n. 8, para. 46.

${ }^{22}$ Case C-352/98 Laboratoires pharmaceutiques Bergaderm SA and Jean-Jacques Goupil v. Commission [2000] ECR I-5291, para. 41. See also Brasserie de Pêcherur/FactortameIII, (see n. 16), para. 42.

${ }^{23}$ Opinion of Léger AG in Case C-224/01 Gerhard Köbler v. Republik Österreich [2003], 8.4. 2003, not yet reported, para. 94. He only admits such possibility in the case of the CFI - para. 93 of the Opinion, where he refers to Case C185/95 P Baustahlgewebe v Commission [1998] ECR I-8417, and Joined Cases C-238/99 P, C-244/99 P, C-245/99 P, C-247/99 P, C-250/99 P to C-252/99 P and C-254/99 P Limburgse Vinyl Maatschappij and Others v Commission [2002] ECR I-8375.

${ }^{24}$ Opinion, see n. 23, para. 94.
} 
For citation please use CYELP, volume 1. More information available at www.cyelp.com

Treaty). ${ }^{25}$ The Court has been criticised in the past ${ }^{26}$ for applying different standards, and the conclusion of the Advocate General only confirms the tenability of this critique.

\subsection{Comparative legal reasoning of the Court of Justice}

Academic opinion from Judge K. Lenaerts observes that only in a few cases has the Court of Justice referred expressly to comparative law. ${ }^{27} \mathrm{~T}$. Möllers remarks that "[proper comparative arguments] could enhance the acceptance of European law and also provide a role-model for national courts". ${ }^{28}$

The Court relied on a comparative analysis made by Advocate General and found that "application of the principle of State liability to judicial decisions has been accepted in one form or another by most of the Member States". ${ }^{29}$ However, as will be shown further, this analysis is far from convincing and hardly enhances the acceptance of the judgement in national courts.

The Advocate General starts with the contention that all the Member States accept the principle of state liability for judicial acts, and then adds that all accept this principle, except Ireland. And then more "exceptions" keep coming. In the United Kingdom and the Netherlands, responsibility is possible only in cases of infringement of the rules laid down in Article 5 (deprivation of liberty) or Article 6 of the $\mathrm{ECHR}^{30}$ (relating to the guarantees of a fair hearing). It then follows that "[a]ll the other Member States - excluding the Hellenic, Portuguese and French Republics, where the situation is evolving and more nuanced - accept the principle of State liability irrespective of the nature of the legal rule infringed." 31 Finally, Austria and Sweden limit state liability to the decisions of ordinary courts, excluding those of their supreme courts.

Seeing these "exceptions", one may equally conclude that the principle of state liability is limited in its scope or excluded in its entirety, and it cannot be unequivocally stated that "the principle of State liability - for a judgement of a supreme court in breach of a legal rule - is generally acknowledged by the Member States, or at least a strong tendency in that direction can be detected". 32

It may well be counter argued that the solution depends on a level of generalisation which one accepts when making conclusions from the different national approaches mentioned above. However, the crucial factor for making the damages claim possible may be found in the nature and seriousness of the breach (as in the case of the United Kingdom and the Netherlands) or, to which court the breach can be attributed (e.g. exclusion of supreme courts). It may be deduced even from the Advocate General's analysis that liability for any kinds of breaches committed by all levels of courts (including supreme courts) is known only to six Member States. Regrettably, when reading the Opinion, there are no references to the sources on which the Advocate General

\footnotetext{
${ }^{25}$ Cf. Brasserie de Pêcherur/FactortameIII, see n. 16, para. 42. See also K. Lenaerts, Interlocking Legal Orders in the European Union and Comparative Law [2003] 52 ICLQ 873, p. 887-893.

${ }^{26}$ See T. Tridimas,.Liability for Breach of Community Law: Growing Up and Mellowing Down?, [2001] 38 CMLRev 301, p. 321 and references therein.

${ }^{27}$ See n. 25 (Lenaerts 2003), p. 874.

${ }^{28}$ M.J. Möllers, The Role of Law in European Integration. [2000] 48 Am. J Comp. L, 679, p. 698.

${ }^{29}$ Köbler, see n. 8, para. 48. The relevant part of the Opinion is paras. 77 to 82 .

${ }^{30}$ Convention for the Protection of Human Rights, Council of Europe, Rome 4.11. 1950.

${ }^{31}$ Opinion, see n. 23, para. 80. Emphasis added.

${ }^{32}$ Ibid., para. 82.
} 
established his analysis. Hence, we do not know how deep the analysis was - whether he compared only the legal texts or whether he took into account the "law in action" and saw how liability is actually applied. Then it is questionable whether this comparative analysis indeed leads to "a right balance between the interests of Community law and the acceptability of [the] ruling to the national legal orders", ${ }^{33}$ which, according to $\mathrm{K}$. Lenaerts, is a function of the use of the comparative method.

\section{3 (Non-) use of the balancing argumentation}

One of the strongest counterarguments against the responsibility of a State for judicial acts has been the principle of res judicata. ${ }^{34}$ From one possible point of view, the claim for damages repeats the original dispute with a changed legal basis, but with an identical merit. The unsatisfied party to the original dispute "appeals" this original decision by claiming the damages which this decision allegedly caused. The court hearing the damages claim must at the same time review the original decision. Thus, the liability for judicial breaches of Community law may go against the principle of the legal certainty and finality of the disputes.

Nevertheless, when deciding whether liability for judicial acts is possible in Community law, the Court of Justice completely excluded such a conflict. It stated that

$[\mathrm{P}]$ roceedings seeking to render the State liable do not have the same purpose and do not necessarily involve the same parties as the proceedings resulting in the decision which has acquired the status of res judicata. The applicant in an action to establish the liability of the State will, if successful, secure an order against it for reparation of the damage incurred but not necessarily a declaration invalidating the status of res judicata of the judicial decision which was responsible for the damage. In any event, the principle of State liability inherent in the Community legal order requires such reparation, but not revision of the judicial decision which was responsible for the damage. ${ }^{35}$

It is obvious that the Court of Justice interpreted the principle of res judicata in a strict formal manner. Of course, the parties are not identical - an unsatisfied party is seeking damages against the State, not the party to the original dispute. Also, the subject matter of this second dispute is different - now being the claim for damages. It is also true that the court deciding on the damages does not necessarily have to declare the original decision invalid. Nevertheless, when reviewing the correctness of this decision, the court hearing the claim for damages undermines the legitimacy of the original decision as well as the legal certainty of the party which was satisfied in the original dispute.

Even more striking, further along in the judgement, where the question of the conditions of such liability is dealt with, the Court of Justice states:

[...] regard must be had to the specific nature of the judicial function and to the legitimate requirements of legal certainty [sic!], as the Member States which submitted observations in this case have also contended. State liability for an infringement of Community law by a decision of a national court

\footnotetext{
${ }^{33}$ See n. 25 (Lenaerts 2003), p. 883.

${ }^{34}$ All intervening parties, together with Austria and the Commission, referred to this principle. This principle is also discussed by both authors mentioned above who dealt with judicial responsibility before the Köbler Case - see n. 19, (Toner 1997), p. 176; (Anagnostaras 2001), p. 289, in particular the latter.

${ }^{35}$ Köblersee n. 8, para. 39. See also Opinion (n.23), para. 101.
} 
adjudicating at last instance can be incurred only in the exceptional case where the court has manifestly infringed the applicable law.

Contrary to its previous view, here the Court is aware of the conflict of the principles to make good any damage (or, l'effet utile of Community law) and of the legal certainty (and more particularly, though not expressly stated res judicata) and limits the liability only to "the exceptional case where the court has manifestly infringed the applicable law". However, the rationality of such reasoning is contestable. The Court should have submitted balancing argumentation weighing the conflict of the principles.

In describing the balancing argumentation, R. Alexy states that "the greater the degree of nonsatisfaction of, or detriment to, one right or principle, the greater must be the importance of satisfying the other" ${ }^{36}$ When a court uses balancing, it must firstly establish the degree of nonsatisfaction of, or detriment to, the first principle (in our case it would be the principle of legal certainty). Next comes defining the importance of the satisfaction of the competing principle (legal protection of individuals or l'effet utile). Finally, the court may arrive at the conclusion, giving reasons for favouring one of the principles.

In the Köbler Case, the Court of Justice first excluded any possible conflict (even though in another part of the judgement it admits that such a conflict exists). Then the Court merely stated that there is another interest which must be taken into account when establishing the seriousness of the breach, without balancing the competing interests.

\section{4 (Mis)application of the "sufficiently serious breach" test}

The condition of a "sufficiently serious breach" proved to be crucial for the outcome of the Court of Justice's ruling in the Köbler Case. By ruling that the breach did not satisfy this strict test, the Court excluded Austria's liability and set aside interesting questions regarding, for example, causality of the damage. ${ }^{37}$

According to the Court of Justice, three conditions must be fulfilled conjunctively to hold a Member State liable for a breach of Community law: the rule of law infringed must be intended to confer rights on individuals; the breach must be sufficiently serious; and there must be a direct causal link between the breach of the obligation incumbent on the State and the loss or damage sustained by the injured parties. ${ }^{38}$

Specifying the second of these conditions (seriousness of the breach), the Court of Justice holds that certain factors which characterise the situation put before a national court shall be taken into account. "They include in particular, the degree of clarity and precision of the rule infringed, whether the infringement was intentional, whether the error of law was excusable or inexcusable, the position taken, where applicable, by a Community institution and non-compliance by the court in question with its obligation to make a reference for a preliminary ruling under the third paragraph of Article 234 EC. "39

\footnotetext{
${ }^{36}$ R. Alexy,. On Balancing and Subsumption. A Structural Comparison. [2003] 16 Ratio Juris 433, p. 436.

${ }^{37}$ Cf. G. Anagnostaras, The Allocation of Responsibility in State Liability Actions for Breach of Community Law: a Modern Gordian Knot? [2001] 26 ELRev. 139, p. 142 et seq.

${ }^{38}$ Köbler, see n. 8, para. 51.
} 
However, when adjudicating whether a breach had been committed by the Verwaltungsgerichtshof, the Court disregarded the standard it had set above. It merely stated that the Verwaltungsgerichtshof had breached Art. 234 EC on the preliminary ruling procedure as interpreted in the CILFIT ${ }^{40}$ and the Treaty provisions on the Free Movement of Workers. ${ }^{41}$ When coming to the conclusion that the breach committed was not sufficiently serious, it did not refer to any of the above-mentioned factors. Instead, it stated that "it was owing to its [the Verwaltungsgerichtshof's] incorrect reading of that judgement that the Verwaltungsgerichtshof no longer considered it necessary to refer that question of interpretation to the Court". ${ }^{42}$

In conclusion, every national court is by this interpretation excused in the case where it has "incorrectly read" the judgements of the Court of Justice. Whether (and in which way) the test for sufficiently serious breach is even applicable remains questionable and we must wait for another judgement of the Court on the matter. ${ }^{43}$

\section{REFLECTIONS FROM THE OTHER SIDE}

In criticising the judgement, the author does not contest its necessity or benefit for the Community. If we accept that national courts are the key actors in promoting Community law on the national level, we must also welcome the judgement as another tool for controlling the way they fulfil their obligations stemming from the Treaty. This applies even more at the time of the Enlargement, and this may be seen as one of the rationales behind the decision. ${ }^{44}$

This explanation is supported by the fact that, at the time the judgement in the Köbler Case was given, the Court of Justice was dealing with an infringement case where Italy was being taken to the Court for, inter alia, the persisting practice of its courts in breaching Community law. ${ }^{45}$ For a long time this had been allegedly excluded by the argument that the co-operation and trust between the Court of Justice and national courts would have been disrupted. ${ }^{46} \mathrm{We}$ may see this infringement procedure as a warning to national courts in the New Member States to take Community law seriously.

The critique in this paper is directed towards the way the Court of Justice has reasoned in its judgement in the Köbler Case. From the Enlargement perspective, the need to establish the

\footnotetext{
${ }^{39}$ Köbler, see n. 8, para. 55. In the next paragraph of the judgement, the Court adds: "In any event, an infringement of Community law will be sufficiently serious where the decision concerned was made in manifest breach of the case-law of the Court in the matter [...]". See the discussion further in part 4.2.

${ }^{40}$ Case 283/81 CILFIT [1982] ECR 3430. As regards the obligation to refer the preliminary question to the Court of Justice, cf. see n.14 (Lenaerts, Arts, Bray 1999), p. 45-55 or (Schermers, Waelbroeck 2001),p. $266-285$.

${ }^{41}$ Köbler, see n. 8, paras. $118,119$.

${ }^{42}$ Ibid., para. 123, emphases added.

${ }^{43}$ Case C-173/03 Fallimento 'Traghetti del Mediterraneo' SPA v. Italian Republic, [2003] OJ C 158/10, is now pending in the Court.

${ }^{44} \mathrm{Cf}$. the reflection on that in Czech: M. Bobek, Odpovědnost členského státu za akty moci soudní; př́spěvek Evropského soudního dvora krozšíreni Evropské unie? [Member States' Liability for Judicial Breaches of Community Law - A Contribution of the European Court of Justice to the Enlargement?] Časopis pro právní vědu a praxi 4/2003, p. 191-205. Another possible explanation may be also the reform of EC competition law implemented by Council Reg. 1/2003 [2003] OJ L 1/1 of 16 December 2002 on the implementation of the rules on competition laid down in Articles 81 and 82 of the Treaty, shifting the enforcement to the national level and allowing national courts direct application of Art. 81 EC.

${ }^{45}$ Case C-129/00 Commission v. Italy [2003] 9.12. 2003, not yet reported.

${ }^{46}$ Cf. see n. 14 (Schermers, Waelbroeck 2001), p. 630-631.
} 
For citation please use CYELP, volume 1. More information available at www.cyelp.com

Court's legitimacy and to foster respect for its case-law in the new Member States and their courts is of vital importance, in particular for the proper integration of Community law and its values.

In these States, the Court of Justice (or its judgements) might face different kinds of judges sitting in ordinary courts than it is used to from the current 15 Member States. As Z. Kühn remarks:

The problematic curricula of the post-communist judiciary discourage many legal experts. The soon to be European judges come from authoritarian and totalitarian traditions; they were trained under a centrally planned economy; and last but not least, many of them received legal education which might be considered rather problematic from the Western view. ${ }^{47}$

The problematic relationship between the New Member States' constitutional courts and ordinary courts foreshadows possible problems in their prospective relation to the Court of Justice. Z. Kühn observes the friction between these two branches and finds an explanation for this in the different ideologies of adjudication. In the case of the latter branch, constitutional courts followed the evolution of the Western world, abandoning the strict textual positivism and ideology of bound decision-making. Their reasoning is more value oriented, using open methods of interpretation. ${ }^{48}$ In contrast, ordinary courts are still "enslaved" in the past approaches to "limited law". 49 The Czech Constitutional Court forces ordinary courts towards these changes and emphasises that they are not

[a]bsolutely bound by the literal wording of a legal provision, and they can and must deviate from it if such a deviation is demanded by serious reasons of the law's purpose, the history of its adoption, systematic reasons or any principle deriving from the constitutionally conform legal order ... In doing so, it is necessary to avoid arbitrariness; the decision of the court must be based on a rational argumentation..$^{50}$

This Constitutional Court's approach then led to controversies between it and ordinary courts, and gave rise to reflections in the doctrinal debate. ${ }^{51}$

The Court of Justice works in a very similar way, using teleological, comparative or contextual methods, ${ }^{52}$ which are still considered to be above-standard by the prevailing part of the Czech

\footnotetext{
${ }^{47}$ Z. Kühn, Worlds Apart. Western and Central European Judicial Culture at the Onset of the European Enlargement, to be published in [2005] Am. J Comp.L, on file with the author.

${ }^{48}$ The collection of essays of one of the prominent judges of the Czech Constitutional Court serves as an excellent example: P. Holländer, Ústavněrpávní argumentace [Constitutional Reasoning], Prague, Linde, 2003. It seems to the author that the disputes regarding the difference between interpretation and reasoning in constitutional law and ordinary law reflect the same evolution as in, for example, Germany in the first ten years of the functioning of the Bundesverfassungsgericht in the beginning of the 1960s.

${ }^{49}$ D. Lyons, Justification and Judicial Responsibility. [1984] 72 Cal. Law R., 178 as cited in n. 47 (Kühn 2004). For a current outline of some remaining problems of "the justice in transition", see W. Sadurski,. "Decommunisation", "Lustration", and Constitutional Continuity: Dilemmas of Transitional Justice in Central Europe, EUI Working Paper Law, 2003/15, http://www.iue.it/PUB/law03-15.pdf (14.1. 2004).

${ }^{50}$ ÚS vol. 7, p. 87, the decision Pl. ÚS 21/96 as cited in n. 47 (Kühn 2004).

${ }^{51}$ Cf. further, when the Czech Supreme Court refused to follow the Constitutional Court's decision regarding the principle $\mathrm{Ne}$ bis in idem. We discuss the topic when dealing with the effect of Court of Justice's case-law in the new Member States. See infra p. 17-18.

${ }^{52}$ A.A. LLorens, The European Court of Justice, More than a Teleological Cour, [1999] 2 CYELS, 373.
} 
doctrine and, as such, are taught at law faculties. ${ }^{53}$ These methods will not be in every case understood and accepted on the national level by ordinary judges. When the Court reasons in cases like Köbler, it should be borne in mind that the more persuasive it is, the better it would be accepted.

Let us now continue with reflections of the Köbler judgement on the national level, again with particular focus on the new Member States. Firstly, we will deal with the national courts' obligation to refer preliminary questions to the Court of Justice. Then, we will discuss in brief the emergence of the "European precedent", i.e. the effects of the Court's case-law as a source of persuasive authority or even a source of law, and also its effect on the hierarchisation of the European judiciary.

\subsection{Preliminary references - CILFIT revival}

In Köbler, the Court of Justice found that, since the Verwaltungsgerichtshof did not maintain its request for a preliminary ruling, it breached the obligation it had according to Art. $234 \mathrm{EC}$. This provision states that a court or tribunal against whose decisions there is no remedy under national law, when dealing with certain questions of interpretation of Community law, is obliged to refer such questions to the Court. ${ }^{54}$ The Court has widened this obligation to all courts in cases where the validity of a Community act is in question. ${ }^{55}$

For the highest courts, the obligation was interpreted by the Court of Justice in CILFIT. ${ }^{56}$ According to the Court, a national judge does not have to refer the question when the question of Community law raised in proceedings before him is irrelevant for his decision, or when the Community provision in question has already been interpreted by the Court, or finally when the correct application of Community law is so obvious as to leave no scope for any reasonable doubt. $^{57}$

The last one of the conditions, known as acte clair, is the most controversial. When relying on it, the national judge has to bear in mind that Community legislation is drafted in several languages, all being equally authentic. An interpretation thus involves a comparison of the different language versions. Furthermore, Community law uses terminology which is peculiar to it, and its legal concepts do not necessarily have the same meaning in Community law as in the law of the various Member States. Finally, every provision of Community law must be placed in its context and interpreted in the light of the provisions of Community law as a whole, regard being given to the objectives thereof and to its state of evolution at the date on which the provision in question is to be applied. ${ }^{58}$ No wonder that some commentators viewed these conditions as being unachievable. ${ }^{59}$

Nevertheless, the real effect of the CILFIT test - its actual application by highest national courts is contestable. For example, the Conseil d'Etat relied on the acte clair doctrine between 1

\footnotetext{
${ }^{53}$ A. Gerloch, Teorie práva [A Theory of Law], Dobrá Voda, A.Čeněk, 2001,p. 128-129.

${ }^{54}$ See Art. 234 EC.

${ }^{55}$ Case 314/85 Foto-Frost [1987] ECR 4199.

${ }^{56}$ See n. 37.

${ }^{57}$ CILFIT, see n. 40, para. 21.

${ }^{58}$ Ibid., paras. 18-20.

${ }^{59}$ For example, H. Rasmussen, The European Court's Acte Clair Strategy in C.I.L.F.I.T,. [1984] 9 ELRev 242.
} 
January $1978^{60}$ to 30 September 2001 in 191 cases. ${ }^{61}$ Even more striking is the disregard of the CILFIT test by the German Constitutional Court - Bundesverfassungsgericht (BVerfG) when protecting the constitutional right to a lawful judge. ${ }^{62}$ The refusal of ordinary courts to refer a question of Community law to the Court of Justice may in some instances constitute a breach of this right. This occurs when an ordinary court arbitrarily (auf Wilkür beruhend) does not make a reference to the Court of Justice. The conditions of this arbitrariness are further specified by the BVerfG in another judgement. ${ }^{63}$ What is interesting is that these conditions were formulated differently from the CILFIT test set by the Court of Justice. According to the BVerfG these conditions of arbitrariness are as follows: fundamental breach of the obligation to refer - the court in question was in doubts when interpreting Community law; the court intentionally diverged from the settled interpretation of the question by the Court; finally, there is no case-law of the Court, or this case-law does not fully cover the matter in its entirety.

However, if one looks at the well-known Maastricht-Urteil, ${ }^{64}$ when dealing with the interpretation of the Treaty (although formally interpreting the German Basic Law), the BVerfG referred no question to the Court of Justice. It instead heard the Director General of the Commission Legal Service. It may well be considered to be in breach of Community law. ${ }^{65}$ The position of the BVerfG in the competences debate (Member States vs. the EU) is an explanation. The BVerfG would turn to the latter with a preliminary question only so as to send "its last warning" before it exercises its alleged ultimate Kompetenz-Kompetenz. The former Judge of the BVerfG, D. Grimm, even recommends German lower courts not to refer questions of competence to the Court of Justice, but rather to refer them to the BVerfG in order to allow the latter to express its strong warning itself. ${ }^{66}$

The Köbler Case was an excellent opportunity for the Court of Justice to reconsider the CILFIT test, which, if one is realistic, can hardly be fulfilled. It is even more unachievable for judges in the post-communistic countries. They are faced with "post-modern deconstruction" of their legal orders ${ }^{67}$ when the "legislative whirlwind" brings newer and newer laws they have to know and apply. It is not only due to the transition, but also because these countries had to implement an immense bulk of acquis communautaire to fulfil conditions for membership in the EU. P. Holländer mentions the Czech Code of Civil Procedure, which had been substantially re-codified towards 1 January 2001. However, the amendments to this principal re-codification were considered in spring of the same year and by summer 2002 it had been (also by indirect

\footnotetext{
${ }^{60}$ Thus it applied the doctrine before it was established by the Court of Justice.

${ }^{61}$ Cf. Preliminary reference to the Court of Justice of the European Communities. General Report (18th Colloquium of Associations of the Councils of State and Supreme Administrative Jurisdictions of the European Union, Helsinki, 20.-21.5. 2002), http://193.191.217.21/colloquia/2002/gen_report_en.pdf (29.11. 2003), p. 29.

${ }^{62}$ Solange II, BVerfGE 73, 339, [1987] 3 CMLR 225 or Kloppenburg-Beschluss, BVerfGE 75, 223 [1988] 3 CMLR 1.

${ }^{63}$ Absatzfonds, BVerfGE 82, 159.

${ }^{64}$ Maastricht, BVerfGE 89, 155. Available in English in A. Oppenheimer, The Relationship between European Community Law and National Law: the Cases. Volume I. Cambridge, Cambridge University Press, 1994, p.526-575.

${ }^{65}$ See n. 7 (Mayer 2003), p. 7.

${ }^{66}$ D. Grimm, The European Court of Justice and National Courts: The German Constitutional Perspective after the Maastricht Decision, [1997] 3 Col. ELJ, 229, p. 241.

${ }^{67}$ Cf. n. 48 (Holländer 2003), p. 11-23. The essay symptomatically entitled "The Judge today: a barrier to a postmodern deconstruction or an industrial factory for decision-making?" has also been published in English: J. Priban, P. Roberts and J. Young (eds.), Systems of Justice in Transition: Central European Experiences Since 1989. Aldershot, Ashgate Publishing, 2003,p. 77-93.
} 
amendments) amended 18 times. ${ }^{68}$ The judges are then in his view "industrial factories for decision-making" rather then rationally ruling bodies.

These judges will hardly have time to learn anything more than the mere basics of Community law. This is also due to the fact that many of them were trained in the times when the Community law was unknown to law faculties. One cannot imagine such judges dealing with problematic questions of interpretation of Community law and applying all the requirements of the CILFIT test. It is excluded due to their limited language competence (which is a general problem of the CILFIT test - a judge knowing all 11 official languages, and in the future, 21, would have needed to have spent all his life learning them, and would not have had time to study law as well). The requirement that the judge must be aware of the evolution of Community law at the date of its interpretation is also unrealistic, since, as mentioned above, judges in transition countries have enough problems following the evolution of their own national orders.

There are two possible scenarios. The first one foresees that judges in the New Member States, well aware of their duties resulting from Art. 234 EC and individuals' possibility to claim damages for judicial breaches of Community law, will refer to the Court of Justice every question of Community law which arises before them. This will subsequently give the parties very effective means of prolonging national proceedings, and questions will emerge that are even more dependant on the will of the parties' advocates and their knowledge of Community law. The Court of Justice will be flooded with these questions.

The alternative scenario anticipates that the CILFIT test will be misapplied even more, further undermining the authority of the Court's decisions. National judges will only know that a CILFIT test exists, but since they see that it cannot function, none of them will really care about it. Then the uniformity of Community law will be seriously threatened.

To conclude, it is submitted that when dealing with the question of the obligation to refer questions according to Art. $234 \mathrm{EC}$, the Court should have reconsidered the CILFIT test and should have given a better solution, also taking into account the New Member States' courts.

\subsection{Towards a European precedent or building of the judicial hierarchy in Europe?}

In the Köbler Case the Court of Justice has held:

In any event, an infringement of Community law will be sufficiently serious where the decision [of a national court] concerned was made in manifest breach of the case-law of the Court in the matter. ${ }^{69}$

We may see this statement from two different perspectives. Firstly, the Court gives its case-law a sanction - the sanction of liability of a Member State whose court manifestly breached the caselaw in the matter. It is questionable whether we may still consider the jurisprudence of the Court of Justice only as a persuasive authority, as, for example, J. Bengoetxea asserts. ${ }^{70}$

\footnotetext{
${ }^{68}$ Ibid., p. 11.

${ }^{69}$ Köbler, see n. 8, para. 56. It slightly modifies the wording of the Brasserie de Pêcheur/Factortame III, see n. 16, para. 57. On any view, a breach of Community law will clearly be sufficiently serious if it has persisted despite a judgement finding the infringement in question to be established, or a preliminary ruling or settled case-law of the Court on the matter from which it is clear that the conduct in question constituted an infringement.

${ }^{70}$ J. Bengoetxea, The Legal Reasoning of the European Court of Justice, Oxford, OUP, 1993, p. 69: a decision of the Court is not an "ought-source", it has only valeur d' orientation, or persuasive authority.
} 
Connecting this view with the new Member States, the respect for the Court of Justice's case-law seems more problematic. For example, in the Czech Republic we have seen that tensions exist between the Constitutional Court and ordinary courts. ${ }^{71}$ One of the past disputes concerned the binding force of Constitutional Court decisions. The Supreme Court repeatedly refused to be bound by the Constitutional Court's ruling in the case of an applicant who, because of his religion, declined to exercise obligatory military service. It was contrary to the Czech Criminal Code. After being penalised he was prosecuted again, since he had persisted in his religion and denied the service again. The Constitutional Court applied the principle ne bis in idem and declared the applicant's repeated prosecution (which had reached the Czech Supreme Court) unconstitutional. Facing the judgement of the Constitutional Court, the Supreme Court refused it, arguing that "neither the Constitution nor the Constitutional Court Act contains any provision towards general bindingness of the Constitutional Court's legal opinion expressed in its rulings". ${ }^{72}$ Seeing the Supreme Court as a future Community court, it is doubtful whether its judges will follow the rulings of the European Court of Justice.

Secondly, we may see the above cited part of the Köbler judgement as the Court of Justice's attempt to further build a hierarchy amongst European courts. So far, there is no such hierarchy one cannot say, at least formally, that the Court of Justice is a supreme court of the EU, because no appeal from national courts exists and national courts remain autonomous. Therefore, it is possible (and actually even likely) that a decision of a national court contrary to Community law will never reach the Court of Justice. ${ }^{73}$ But, when allowing claims of damages based on losses suffered by such decisions, the Court creates de facto an appeal procedure enabling their review. ${ }^{74}$ This is because it has a "second" chance to give its interpretation in a case dealing with the damages claim, which is well illustrated by the Köbler Case itself. The Verwaltungsgerichtshof did not refer the question properly and the Court of Justice could not give its interpretation in the matter. But, when dealing with the questions of liability raised in another dispute (now heard by the Landesgericht), the Court of Justice finally had a word to say about the contested increment of Mr Köbler.

One may say that it still depends on the will (or let us say discretion) of a national judge hearing a claim for damages whether he or she refers to the Court the question regarding interpretation of the conditions of liability in the case. A judge sitting in the Landesgericht could have equally well decided not to refer any question to the Court of Justice. Nevertheless, we have seen that in national legal orders liability for judicial breaches poses problems. Thus, it is very likely that a national court would rather refer the questions to the Court of Justice, so as to avoid the sensitive question of having to judge another judge. The Landesgericht did exactly this in the Köbler Case. It is therefore submitted that the referrals regarding the liability of Member States for judicial breaches allow the Court to control the evolution of the interpretation (and application) of Community law on a national level.

\footnotetext{
${ }^{71}$ See supra p. 11-12.

${ }^{72}$ Decision of the Supreme Court, File No. 2 Tzn 10/96, 9/10/1997. Cited in P. Holländer, Nástin právní filozofie [An Outline of the Philosophy of Law], Prague, Všehrd, 2000, p. 46. The reaction of the Czech Constitutional Court may be found in its decision called "Binding Force of Constitutional Court Decisions", III. ÚS. 425/97, available at http://www.concourt.cz/angl_verze/doc/3-425-97.html (1.12. 2003).

${ }^{73}$ Cohn-Bendit Case, mentioned above (see n. 13).

${ }^{74}$ See n. 7a (Komárek 2005), especially p. 13-15.
} 


\section{Conclusion}

This paper has attempted to present some implications posed by the Köbler Case at the time of the Enlargement. They will come to light in the forthcoming years when the ten New Member States' courts become Community courts and their national judges face Community law in their court rooms. Since these judges are important actors for the acceptance of Community law at a national level, from the Community perspective the judgement in the Köbler Case seems beneficial for enhancing the Court of Justice's control over the application and interpretation of Community law in national legal orders. However, as presented in the paper, the judgement was not properly reasoned and has also left many important questions open, thus undermining its legitimacy and acceptance by national judges. 